Терапевтична стоматопогія

УАК 616.314-085.47

СС. І. Бойцанюк, Ю. А. РуАяк, П. Ю. Островський

АВНЗ «Тернопільський державний медичний університет імені І. Я. Горбачевського»

\title{
Застосування апекслокатора у практиці терапевтичної стоматології
}

Резюме. Точне визначення робочої довжини є вирішальним фрактором, що впливає на результат ендодонтичного лікування. Визначення робочої довжини повинно бути проведено зі знанням справи, з використанням достовірних практичних та ефективних методів дия отримання точних результатів. Зазвичай виконується за допомогою тактильних відчуттів, рентгенографічних методів або апекслокаторів. Проте всі ці методи мають свої обмеження. Рентгенографічний метод є одним 3 найпоширеніших і надійних методів, який використовують при визначенні робочої довжини. Проте точності важко досягти в цій техніці, тому що апікальне звуження не завжди буде ідентифіковано.

Електронне визначення робочої довжини кореневих каналів стає все білыш популярним, так як усуває багато з проблем, пов'язаних із рентгенологічними методами.

Ключові слова: кореневі канали, робоча довжина, ендодонтія, електронний апекслокатор.

\section{С. И. Бойцанюк, Ю. А. РуАяк, П. Ю. Островский}

ГВУЗ «Тернопольский государственный медицинский университет имени И. Я. Горбачевского»

\section{Применение апекслокатора в практике терапевтической стоматологии}

Резюме. Точное определение рабочей длины является решающим фактором, влияющим на исход эндодонтического лечения. Определение рабочей длины должно быть проведено со знанием дела, с использованием достоверных практических и эффективных методов для получения точных результатов. Определение длины корневого канала обычно выполняется с помощью тактильных ощущений, рентгенографических методов или апекслокаторов. Однако все эти методы имеют свои ограничения. Рентгенографический метод является одним из самых распространенных и надежных методов, который используется при определении рабочей длины. ОАнако точности трудно достичь в этой технике, потому что апикальное сужения не всегда будет идентифицировано.

Электронное определение рабочей длины корневых каналов становится все более популярным, так как устраняет многие из проблем, связанных с рентгенологическими методами.

Ключевые слова: корневые каналы, рабочая длина, эндодонтия, электронный апекслокатор.

\author{
S. I. Boytsanyuk, Yu. A. Rudyak, P. Yu. Ostrovskyy
}

SHEI «Ternopil State Medical University by I. Ya. Horbachevsky»

\section{Application of appexlocator in practice of therapeutic dentistry}

Summary. Accurate working length determination is a crucial factor that influences the outcome of root canal therapy. The procedure for establishment of working length should be performed with skill, using techniques that have been proven to give valuable and accurate results and by methods that are practical 
and efficacious. Root canal length determination is commonly performed using tactile sensation, radiographic methods or apex locators. However, all of these methods have limitations. Radiographic method described by Ingle is one of the most common and reliable methods used in determining the working length. However, accuracy is difficult to achieve in this technique because the apical constriction cannot be identified.

The electronic root canal working length determination has become increasingly popular as it eliminates many of the problems associated with radiographic methods.

Key words: root canals, working length, endodontic, electronic apexlocator.

У сучасних умовах конкуренції, в тому числі й на ринку стоматологічних послуг, неможливо здійснювати лікарську практику без впровадження нових методик і технологій. лікування ускладнень карієсу (пульпіту та періодонтиту) являє собою багатоетапний процес, що потребує застосування діагностичного та лікувального обладнання, сучасних матеріалів. Зростають вимоги до кінцевого результату, який повинен не тільки відновлювати втрачену функціональність елементів зубощелепного апарату, а й відповідати найсуворішим естетичним вимогам [3, 9-11].

3 цієї позиції ендодонтичне лікування слід розглядати як трудомісткий цикл маніпуляцій, тому найбільшу кількість помилок і ускладнень на терапевтичному прийомі пов' язано з препаруванням і пломбуванням кореневих каналів [12, 21, 34].

Ще в 1965 році Seltzer i Bender довели, що повноцінне ендодонтичне лікування складається з трьох обов'язкових складових:

- якості механічного і хімічного очищення кореневого каналу;

- стерилізації каналу;

- повної його обтурації [1, 4, 8, 13].

Саме часткове заповнення каналів, або ж навпаки, виведення матеріалу за верхівку кореня дають численні ускладнення у вигляді постпломбувального болю, розвитку запальних і деструктивних змін у періодонті тощо. Тому етап визначення робочої довжини кореневого каналу є чи не найважливішим гарантом успішно проведеного ендодонтичного лікування $[2,7,22,29]$.

Аля проведення успішного пломбування кореневого каналу стоматологу необхідно знати його робочу довжину. Робоча частина кореневого каналу - це відстань між гирлом кореневого каналу та апікальним отвором. На апексі виділяють анатомічну, фізіологічну та рентгенологічну верхівки $[15,16,35]$.
За сучасними даними середня відстань між апікальним звуженням й анатомічною верхівкою становить 0,51 мм. Більш ніж у 90 \% випадків апікальне звуження знаходиться на 0,5 мм від анатомічної та 1,0 мм віА рентгенологічної верхівки [12, 14, 20, 24, 31]. Враховуючи вищесказане, рекомендується проводити обробку кореневого каналу на 0,5 - 2 мм від рентгенологічної верхівки кореня, враховуючи, що зона апікального звуження знаходиться в цьому діапазоні з найбільшою статистичною ймовірністю. Проте такий діапазон значень не дає точної впевненості в якості проведеного лікування. Пломбування кореневого каналу проводять до фрізіологічної верхівки.

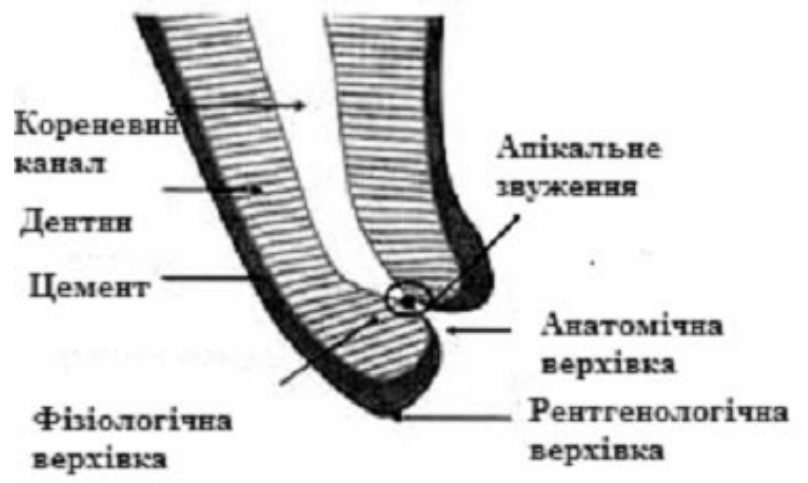

Визначення робочої довжини кореневого каналу - перший і основний етап ендодонтичного лікування. Його якісне виконання забезпечує вільне маніпулювання в каналі при його очищенні та формуванні, безпечне Аля періапікальних тканин. Існує три методи визначення робочої довжини: математичний (розрахункова довжина зуба і кореня); тактильний; рентгенологічний; метод паперового штифта; реакції пацієнта; електронний (за допомогою апекслокатора) [5, 6, 30, 33].

Аля визначення робочої довжини математичним методом використовують спеціальні таблиці. У них наводяться значення довжин 
зубів і коренів, а також співвідношення розмірів коронки і кореня, кількість та частота народження каналів у корені, апікальних отворів у каналі, напрямок вигину каналу $[8,9,16,33]$.

Рентгенологічний метод визначення робочої довжини і прохідності кореневого каналу - найпоширеніший $[2,4,19]$. Рентгенографічне обстеження проводять на етапі діагностування, ендодонтичного лікування з введенням інструмента, контролю пломбування кореневого каналу.

Рентгенологічне зображення кореня зуба з введеним в нього ендодонтичним інструментом дозволяє визначити не тільки довжину зуба, але і ступінь прохідності кореневого каналу, напрямок руху інструмента, наявність перфорації, викривленість каналу, стан періодонта $[2,3,7,10]$.

Електрометричний (електронний) метод визначення робочої довжини передбачає використання спеціальних приладів - апекслокаторів [18, 23, 25, 27, 28]. Електронний апекслокатор є одним з проривів, що привів електронну науку в традиційну ендодонтичну практику.

Апекслокація базується на сталості значень електричного опору тканин. Принцип їх роботи заснований на тому, що періодонт виробляє електричний потенціал, відмінний віА дентину. Електрод, закріплений на губі пацієнта, замикає електричну дугу, імпульс від якої переводиться на монітор. Швидкість пробігу електричного імпульсу по дузі (від кінчика файлу до апікального звуження) автоматично вираховує робочу довжину [14, 26, 33]. Апекслокатори в даний час використовують Аля визначення робочої довжини і в якості важливого доповнення до рентгенологічного дослідження.

\section{Історія розвитку ендометрії}

У 1962 році японський вчений Sunada створює перший апекслокатор, відкривши феномен, що електричний опір Аля постійного струму між верхівковим періодонтом і слизовою оболонкою порожнини рота є величина стала (5 кОм), а між слизовою і будь-якою ділянкою зуба вона значно більша $[14,32]$.

Перший прилад генерував електричні хвилі однакової частоти і міг фіксувати опір тканин. Пасивний електрод розміщали на губі пацієнта, а активний - на ендодонтичному інструменті. При зіткненні ендодонтичного інструмен- та з періодонтом електричний ланцюг замикався і прилад показував довжину кореневого каналу. Апарати з постійним електричним струмом (омметри) при визначенні робочої Аовжини давали помилки, зумовлені поляризацією електродів, наявністю в каналі рідин, а сама процедура часто була болючою [19].

Починаючи з третього покоління апекслокатори визначають імпеданс за допомогою змінних струмів різної частоти.

У 1994 році Кобаяші й Суду запропонували апекслокатор Root ZX (J. Morita ), в якому для визначення довжини кореневого каналу було застосовано так званий метод співвідношення, що позволило одночасно вимірювати опір струму двох частот (8 кГц і 0,4 кГц) і знаходити загальний коефіцієнт опору, що відображає положення файлу в каналі $[14,23,28]$. Це вимір є стабільним і вказує на присутність електролітів у пульпарній тканині. Він забезпечував високу точність вимірювання навіть при роботі у вологих каналах, що не було представлено раніше.

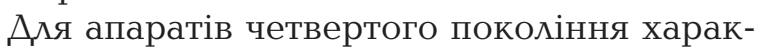
терно те, що вони заміряють і порівнюють комплексні електричні характеристики каналу за допомогою двох або більше частот електричного імпульсу за методом проф. Сонада. Цей тип апаратів забезпечує плавну візуалізацію всього процесу проникнення верхівки канального інструмента і високу точність визначення місця фізіологічного розчину (понад 80 \%). Цей метод допомагає при діагностичному процесі за допомогою визначення моменту торкання пульпних залишків, латеральних каналів, перфорації тощо. Істотним недоліком методу є вимога до роботи у відносно сухих або частково підсушених каналах. Це призводить до необхідності в деяких випадках проводити додаткове підсушування, а при рясному ексудаті або кровотечі метод стає неможливим.

Апекслокатори п'ятого покоління (наприклад Ендо Аналізер Модел (8005), аналітик Сіброн Аентал) здатні прораховувати опір струму п'яти частот $(0,5,1,2,4$ і 5 кГц). Принцип інтерпретації вимірювань величини електричного опору в показники довжини (від кінчика інструмента у каналі на рівні малого апікального отвору) проводять шляхом перерахунку за закладеною в програмі приладу формулою порівняльним методом, що дає більш точні й швидкі показники. 
Оскільки для подібних приладів періодонт більше не слугує визначальною константою, патологічні зміни у періапікальних тканинах або порушення зв'язкового апарату зуба не можуть вплинути на результати вимірювання. Подальші дослідження подібних приладів вказують на те, що точність визначення робочої довжини кореневого каналу з їх допомогою складає 95 \% і вище $[18,25,26]$.

Сучасні моделі апекслокатора, які сьогодні широко представлені на ринку стоматологічного обладнання, мають такі характеристики:

- повністю автоматичні;

- гарантовані миттєві й точні вимірювання;

- інтерактивне функціонування, простота у використанні;

- вбудований режим демонстрації забезпечує апекслокатору легкість в обігу;

- зручний Аля користувача інтерфейс апекслокатора позволяє швидко оволодіти новим приладом;

- функцію віртуальний апекс (установка точки в апікальній зоні, при досягненні якої буде різко збільшуватися частота звукових сигналів);

- звукові сигнали з регулюванням гучності;

- вбудовану функцію самотестування та захисту;

- автоматичне відключення;

- заряджається акумулятор.

Апекслокатор забезпечує все для того, щоб лікар зміг виконати високоточну обробку каналу. При розробці даних приладів враховують новітні досягнення світової цифрової промисловості та результати стоматологічних досліджень при оцінці вимірювань в зубному каналі. Положення ендоголки в каналі та інша необхідна інформація відображаються на великому кольоровому дисплеї. Апекслокатор володіє ергономічним сучасним дизайном. 3 метою збереження інфекційної безпеки пацієнта прилад зроблений з легкодезінфікуючих матеріалів. Все це дозволяє апекслокатору стати незамінним в оснащенні будь-якого стоматологічного кабінету.

Класичною моделлю апекслокатора є EMF-100. Вона оснащена всім необхідним: великим зручним LCD-дисплеєм із розширеною шкалою вимірювання відстані від апекса, на нижній сходинці у збільшеному вигляді представлений 2 мм відрізок кореневого каналу безпосередньо перед апікальним отвором, що дозволяє робити вимірювання довжини каналу з більш високою точністю.

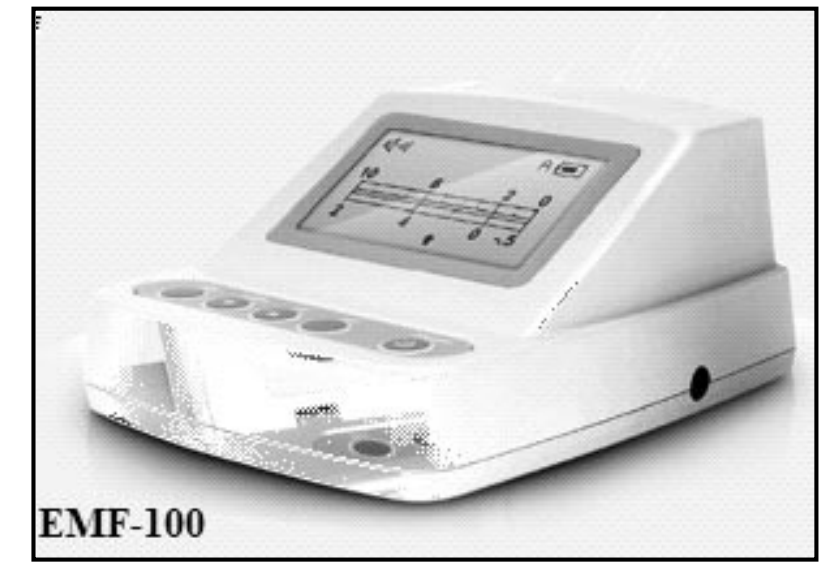

Аоступна візуально інформація і супровоАжуючий їі аудіосигнал, безумовно, допомагають лікареві орієнтуватися у вимірах при проведенні ендодонтичного лікування. Отже, на екрані доступна інформація для стоматолога про рівень звукового сигналу, рівень заряду батареї та індикатор апекса.

У моделі передбачена спеціальна система подачі слабкого струму, завдяки чому пацієнт не відчуває дискомфорту. Кількість заряду батареї відображає індикатор на екрані приладу, функція автоматичного відключення приладу дозволяє економити заряд і забезпечує безпечну роботу. Аікар може вибрати варіант роботи приладу: віА лужної чи акумуляторної батареї. Управління апекслокатором здійснюється за допомогою зручної панелі, на якій розташовані кнопка включення/виключення і кнопка регулювання параметрів.

Результатом тривалих розробок інженерів S-Denti з'явилася модель EMF-100 Deluxe, за Аопомогою якої можна проводити вимірювання каналів, що перебувають у будь-якому стані. Безумовним плюсом моделі є можливість змінювати кут нахилу дисплея апекслокатора і тим самим індивідуально налаштовувати положення екрана. Прилад оснащений функцією самодіагностики, що дозволяє в будь-який час перевірити справність приладу.

Важливою відмінною рисою ЕМF-100 Deluxe $є$ можливість підключити апарат до монітора за допомогою VGA-кабеля. Ажерелом живлення слугує 3 батареї, що забезпечують тривалу безперебійну роботу апарату.

Особливе місце в модельному ряді S-Denti займає апекслокатор п'ятого покоління EMF-100 DeLux i-root. Апарат відрізняється не тільки яскравим і стильним дизайном - функціонал моделі не залишить байдужим жодного 


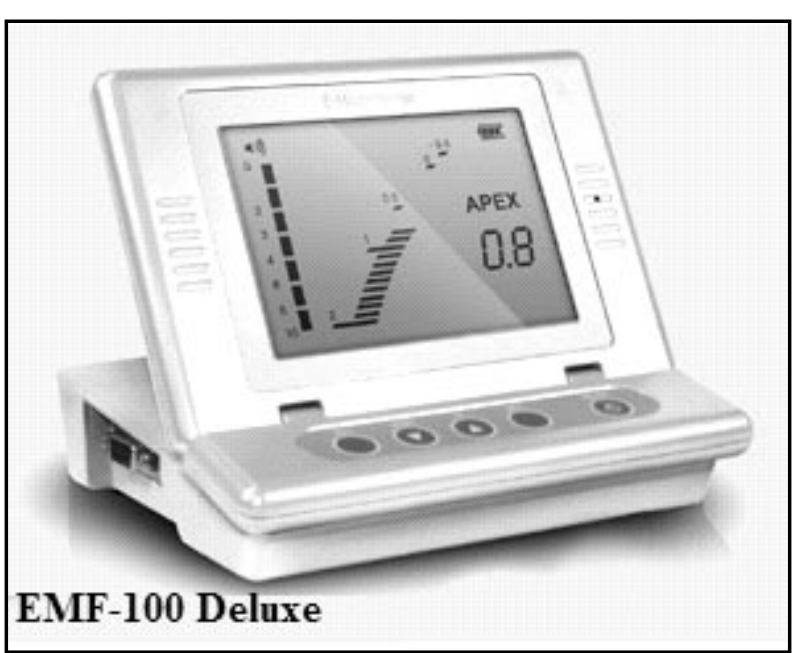

фахівця. На кольоровий LCD-дисплей апарату виводиться повна інформація про дентальний канал. Надійна система безпеки і функція самодіагностики дозволяють лікарю повністю покластися на показники приладу під час лікування. Інженери вдосконалили модель і оснастили EMF-100 DeLux i-root опцією підключення до ПК через USB-вихіА.

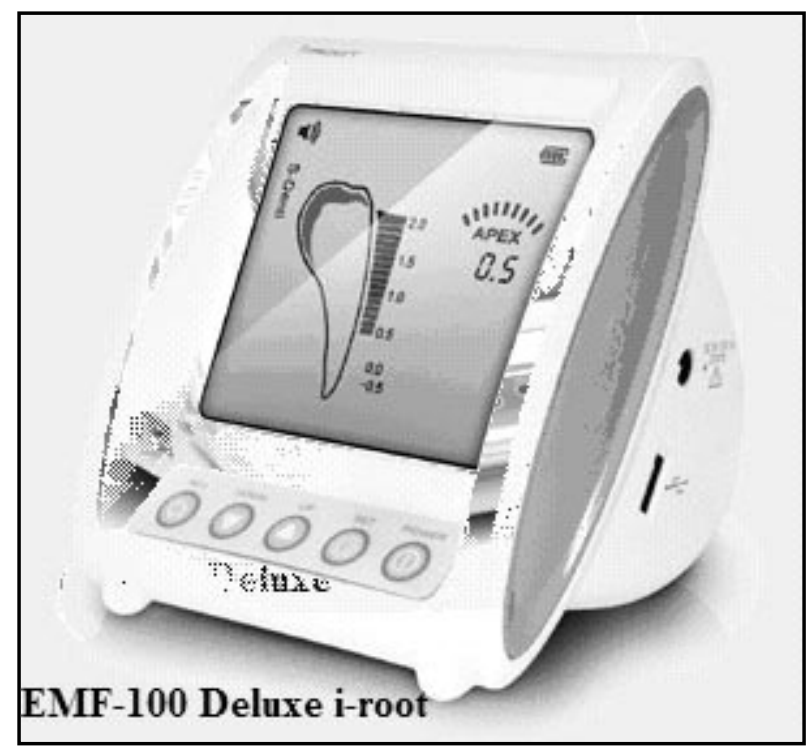

Крім того, лікар має можливість самостійно регулювати гучність сигналу апекслокатора. Модель працює від зарядних літійіонного акумулятора, а в разі необхідності система сигналізує, що джерело живлення скоро розрядиться. Таким чином, модель має всі переваги лінійки ЕMF-100 і при цьому володіє рядом додаткових можливостей.

Інновацією для виробника стала розробка моделі EMF 100 DeLux i-root Endo. Вона має вбудований ендомотор і дозволяє надавати кореневим каналам форму конуса, що знижує ризик ускладнень після пломбування каналу. Користувач має можливість регулювати швидкість обертання, та встановлені налаштування швидкості мотора можуть бути збережені.

Модель забезпечує високу якість обробки каналів і значно скорочує час препарування. Відсутність інерції дозволяє істотно знизити ймовірність поломки інструмента в момент різкого знятті навантаження. Модель EMF-100 DeLux i-root Endo - втілення унікальної технології в області ендодонтичних систем.

Всі діагностичні прилади представленого модельного ряду повністю автоматизовані. Сучасні можливості дозволили оснастити апекслокатори надійною системою діагностики несправностей і режимом економії енергії. Вони прості в експлуатації і не вимагають спеціалізованого технічного обслуговування, працюють у різних режимах і легко обробляються за допомогою дезінфікуючих серветок. Подвійна частота апекслокаторів S-Denti (500 Гц і 5 кГц) забезпечує підвищену точність і дозволяє стоматологу регулювати вплив на канал при вимірюванні, знижуючи Аискомфорт пацієнта.

Новий вдосконалений цифровий визначник верхівки кореня (апекслокатор) від NSK розроблений для точного вимірювання довжини каналу в будь-яких середовищах, включаючи сухі, вологі або за наявності крові у каналі.

Технологія багаточастотного вимірювання апекслокатора іРех фільтрує сторонні сигнали,

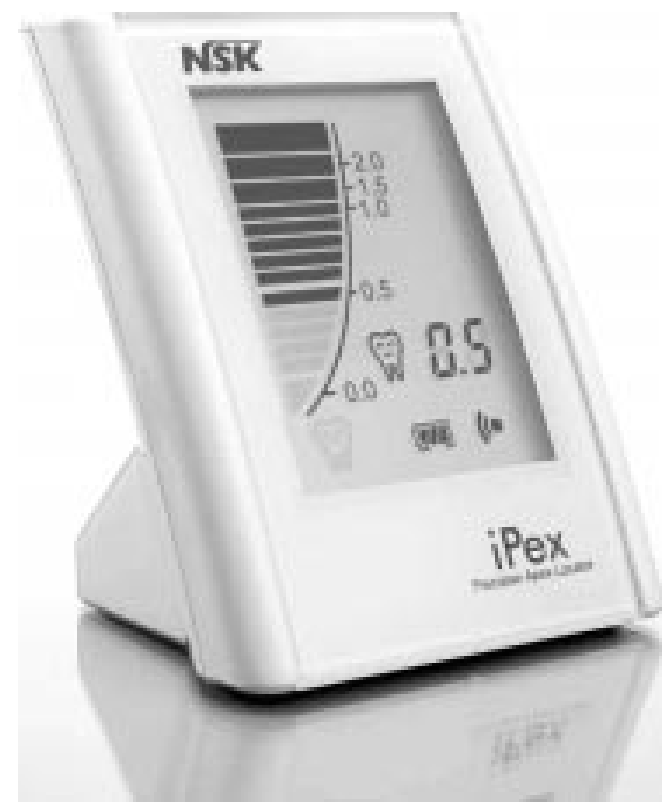


що є у нелінійних каналах, та інші нестанАартні сигнали. іРех автоматично вибирає найкращі комбінації частот відповідно до стану кореневого каналу пацієнта.

Переваги приладу:

- миттєві точні вимірювання довжини каналу;

- зручний Аля користувача інтерфейс;
- великий РК-дисплей для зручного моніторингу;

- компактна та інтелектуальна конструкція;

- звукова система попередження;

- автоматичне відключення живлення;

- живлення від акумуляторних батарей ААА;

- відсутність необхідності ручного калібрування.
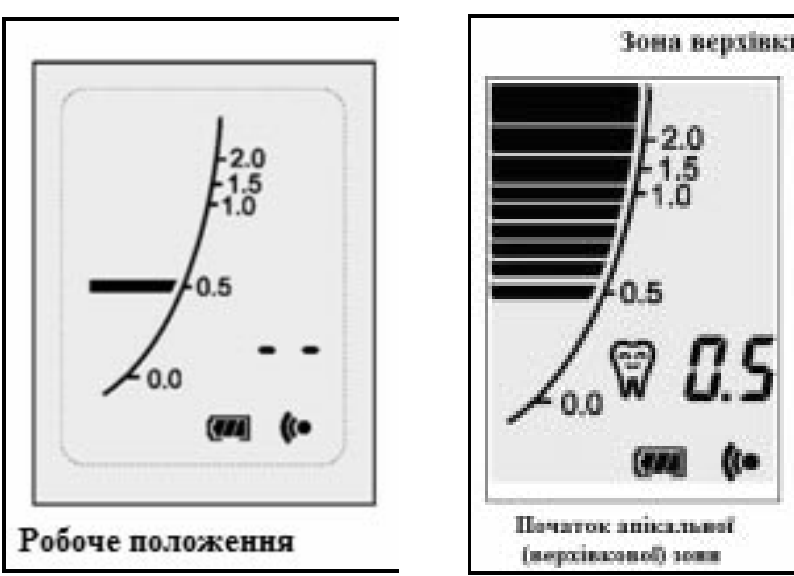

Особливості роботи з апекслокатором

Кілька загальних правил використання апекслокаторів:

- при роботі з апекслокатором всі деталі приладу повинні бути надійно з'єднані, щоб уникнути переривання електричного кола;

- уникайте короткого замикання електричного кола між порожниною зуба і слизовою порожниною рота через амальгамові пломби або слину;

- вимірювання необхідно проводити після ізоляції зуба рабердаму;

- кореневий канал не повинен бути абсолютно висушений, так як порушиться електропровідність. У результаті фрайл з електродом буде просунутий за межі каналу, а пристрій не діагностує завершення кореня: робоча довжина буде збільшена;

- додаткові канали реєструються приладом як джерела коливань і розцінюються так само, як і апікальний отвір, що, відповідно, спотворює показники або призводить до зменшення довжини кореневого каналу;

якщо зуб перфоровано або має перелом i файл потрапляє в перфораційний отвір, це призводить до діагностики рівня перфорації, а не апікального звуження.

Переваги застосування електронних апекслокаторів.

1. Відсутність опромінення порівняно 3 рентгенологічним методом.
2. Точність методу. Численні дослідження показали, що застосовуючи метод електронної апекслокації, апікальний отвір ідентифікує у межах 0,5 мм. При традиційній рентгенографії зазвичай відбувається перепломбування каналу, тому що частіше канал ідентифікується більш довгим, ніж насправді.

3. Швидкість методу. Виявлено, що застосування електронних апекслокаторів знижує час ідентифікації апікального отвору.

4. Зменшення проблем при обробці багатокореневих зубів на верхній щелепі. Частіше моляри верхньої щелепи мають додаткові канали або інші особливості їх анатомічної буАови, а також анатомічні особливості будови верхньої щелепи, що ускладнює рентгенологічну ідентифікацію апікального отвору. Апекслокатор працює так само точно у молярах, як і в різцях.

5. Застосовуючи апекслокатор, можна виявити перфорацію стінки каналу, дна порожнини зуба.

Таким чином, очевидна актуальність наукових досліджень у напрямку розробки та впровадження в практичну стоматологію новітніх досягнень сучасних технологій. Вони допоможуть удосконалювати існуючі та розробити нові способи визначення робочої довжини, з метою якісного проведення ендодонтичного лікування у кожній конкретній клінічній ситуації.

ISSN 231 1-9624. Кпінічна стоматопогія. 2014 . № 2 


\section{Список літератури}

1. Беер Р. Иллюстрированный справочник по эндодонтии / Р. Беер, А. М. Бауман, А. М. Киельбаса; пер. с нем.; под ред. Е. А. Волкова. - М. : МЕАпрессинформ, 2006. - 240 с.

2. Боровский Е. В. Эндодонтическое лечение : пособие для врачей / Е. А. Боровский, Н. С. Жохова. М. : АО «Стоматология», 1997. - 63 с.

3. Аукиных А. М. Верхушечный периодонтит : учеб. пособ. / А. М. Аукиных, Ю. Н. Аившиц. - Н. Новгоpoд, 1999. - 92 c.

4. Воробьев Ю. И. Рентгенография зубов и челюстей : учебник. - М. : Медицина, 1989. - 176 с.

5. Ковецкая Е. Е. Методы определения рабочей длины корневого канала / Е. Е. Ковецкая // Современная стоматология. - 2006. - № 3. - С. 35-39.

6. Ковецкая Е. Е. Сравнительная оценка эффективности методов определения рабочей длины корневого канала / Е. Е. Ковецкая // Современная стоматология. - 2006. - № 4. - С. $11-13$.

7. Коуэн С. Эндодонтия / С. Коуэн, Р. Бернс. - СПб. : НПО «Мир и семья-95»; ООО «Интерлайн», 2000. - 696 с. 8. Аатышева С. В. Основные принципы эндодонтического препарирования зубов / С. В. Аатышева, О. И. Абаимова, Е. А. Бондарик // Стоматологический журнал. - 2003. - № 2. - С. 2-6.

9. Аукиных А. М. Пульпит (клиника, диагностика, лечение) / А. М. Аукиных, А. В. Шестопалова. Н. Новгород : Изд-во НГМА, 1999. - 85 с.

10. Луцкая И. К. Практическая стоматология / И. К. Ауцкая - М. : Бел. наука, 2000. - 360 с.

11. Ауцкая И. К. Руководство по стоматологии / И. К. Ауцкая, А. С. Артюшкевич. - Ростов-на А. : Феникс, 2000. - 512 с.

12. Максимовский Ю. М. Как оценить успех или неудачу в планируемом эндодонтическом лечении / Ю. М. Максимовский // Клиническая стоматология. - 1998. - № 3. - С. $4-7$.

13. Мамедова $\mathcal{\lambda}$. А. Современное лечение корневых каналов (технология и инструменты) / ᄉ. А. Мамедова // Новое в стоматологии. - 1997. - № 7. - С. 8- 25.

14. Малык Ю. Эндометрия. Практические рекомендации по использованию апекслокатора / Ю. Малык // Аент Арт. - 2007. - № 1. - С. 33-37.

15. Николаев А. И. Практическая терапевтическая стоматология / А. И. Николаев, А. М. Цепов. - СПб. : СПб. ин-т стоматологии, 2001. - 390 с

16. Николишин А. К. Современная эндодонтия / А. К. Николишин. - Полтава, 1997. - 112 с.

17. Отчет о согласованном мнении Европейского эндодонтического общества об основных показателях качества при эндодонтическом лечении // Эндодонтия today. - 2001. - № 1. - С. 3-12.

18. Крайнов С. В. Оценка эффективности электрометрического метода определения рабочей длины корневого канала на примере апекслокатора
NovApex / С. В. Крайнов, А. Н. Попова, И. В. Фирсова // Актуальные вопросы современной стоматологии : матер. конф. - Волгоград : ООО «Бланк», 2010. $-248 \mathrm{c}$.

19. Петрикас А. Ж. Пульпэктомия : учеб. пособ. Аля стоматологов и студентов / А. Ж. Петрикас - М. : АльфаПресс, $2006-300$ с.

20. Петрикас А. Ж. Строение зуба и пародонта / А. Ж. Петрикас, В. А. Соловьев, О. В. Мансурский // Клинич. стоматология. - 1998. - № 4. - С. $30-32$.

21. Практическая клиническая эндодонтия / пер. с англ.; под общ. ред. проф. И. М. Макеевой / Ф. Ламли, Н. Адамс, Ф. Томсон. - М. : МЕАпресс-инфрорм, 2007. 22. Проект стандартов эндодонтического лечения (СТЭА) / Е. В. Боровский, А. Ж. Петрикас, А. М. Соловьева [и др.] // Клиническая стоматология. - 2003. - № 2. - C. $42-44$.

23. Ex vivo accuracy of three electronic apex locators: Root ZX, Elements Diagnostic Unit and Apex Locator and ProPex / G. Plotino, N. M. Grande, L. Brigante [et al.] // Int. Endod. J. - 2006. - Vol. 39. - P. 408-414.

24. Ingle J. I. Endodontics / J. I. Ingle, L. K. Bakland // Baltimore; Philadelphia. - 1994. - 410 p.

25. Guise G. M. In vitro comparison of three electronic apex locators / G. M. Guise, G. G. Goodell, G. M. Imamura // J. Endod. - 2010. - Vol. 36. - P. 279-281.

26. Gordon M. P. Electronic apex locators. / M. P. Gordon, N. P. Chandler // Int. Endod. J. - 2004. - Vol. 37. P. $425-437$.

27. Kobayashi C. Electronic canal length measurement / C. Kobayashi / / Oral Surg. Oral Med. Oral. Pathol. Oral Radiol. Endod. - 1995. - Vol. 79. - P. 226-231.

28. Kobayashi C. New electronic canal measuring device based on the ratio method / C. Kobayashi, H. Suda // J. Endod. - 1994. - № 3 - P. $21-24$.

29. Kobayashi C. Newly designed electronic canal length measuring device using division method / C. Kobayashi, H. Suda // Int. End. J. - 1993. - Vol. 26. - № 1. P. $21-24$.

30. Methodological considerations in the determination of working length / M. A. Martinez-Lozano, L. FornerNavarro, J. L. Sanchez-Cortes, C. Llena-Puy // Int. Endod. J. - 2001. - Vol. 34. - P. $371-376$.

31. Sharma M. C. Determination of Working Length of Root Canal / M. C. Sharma, V. Arora // MJAFI. - 2010. - Vol. 66. - P. $231-234$.

32. Sunada J. New method for measuring the length of root canals / J. Sunada // J. Dent. Res. - 1962. - № 4. - P. 375-378.

33. Tomas R. Harty's Endodontics in Clinical Practice / R. Tomas, P. Ford // Wright. - 2010. - 312 p.

34. Tronstad L. Clinical Endodontics / L. Tronstad // Copenhagen : Munksgaard. - 1992. - 277 p.

35. Walton R. E. Endodontics: Principles and Practice / R. E. Walton // Elsevier Health Sciences. - 2009 - 474 p. 